\title{
Comparison of Modeling Volatility of Indonesia Banks Using ARCH, GARCH, TARCH and EGARCH
}

\author{
Oleh: \\ Eneng Nurhasanah \\ Fakultas Ekonomi dan Bisnis-Manajemen, Universitas Islam Bandung (Unisba) \\ E-mail: eneng.nurhasanah@unisba.ac.id
}

\begin{abstract}
ABSTRAK
Menurut peringkat PEFINDO, ada 10 Bank terbesar di Indonesia yang mendominasi 65,2\% dari total aset. Dari peringkat ini, penulis menguji model volatilitas yang paling cocok menggunakan ARCH, GARCH, TARCH dan EGARH. Hasil dari $R$-Squared, AIC dan SIC, semua Bank memiliki volatilitas yang sesuai dengan model EGARCH, tetapi ketika penulis memeriksa dua kali untuk model EGACRH dengan pemeriksaan diagnostik deret waktu dan pengukuran fitted model performance, hasilnya menunjukkan bahwa tidak semua Bank masuk ke dalam kategori volatilitas dengan model EGARCH
\end{abstract}

Kata Kunci: ARCH, GARCH, TARCH, EGARCH, Bank

\begin{abstract}
According to the rating of PEFINDO, there are 10 biggest Banks in Indonesia which dominate $65.2 \%$ of the total asset. From this rating, writer examine the best fitted volatility model using ARCH, GARCH, TARCH and EGARH. The result from R-Squared, AIC and SIC, all of the bank have good fitted volatility with EGARCH model, but when writer double checking for the EGACRH model with time series diagnostic checking and fitted model performance measurement, the result show that not all of the banks is fitted volatility by EGARCH model.
\end{abstract}

Key words: ARCH, GARCH, TARCH, EGARCH, Bank

\section{I.INTRODUCTION}

The good profitability and quality of assets will make the banking prospect in Indonesia would be strong and stable in 2014. PT Pemeringkat Efek Indonesia (PEFINDO) is the Indonesian credit rating agency which give the rating for 37 banks in Indonesia, this rating represents $68 \%$ of national total asset. The 33 of the bank have upper id $\mathrm{A}$ - rating, it means that the stability of the banking industry in Indonesia would still strong and possibility to change the rating position in 2014 relatively limited.

From 120 commercial bank in Indonesia, the biggest 10 of them dominate $65.2 \%$ from the total of asset, $65.6 \%$ total of credit, and $66.6 \%$ total of deposit in banking industry. The biggest 10 of banks in Indonesia consists of four government banking, there are Bank Mandiri (BMRI), Bank Rakyat Indonesia (BBRI), Bank Negara Indonesia (BBNI), and Bank Tabungan Negara (BBTN).

Then five foreign banking industry, there are Bank CIMB Niaga (BNGA), Bank Danamon (BDMN), Bank Permata (BNLI), Panin Bank (PNBN) and Bank International 
Indonesia (BNII). Then, one of the independent national private bank is Bank Central Asia (BBCA). PEFINDO has given rating to 9 of 10 the biggest bank in Indonesia except BBCA, with 5 of them achieve the highest rating idAAA (BMRI, BBR, BBNI, BNGA, and BNII), 2 of them achieve id AA+ (BDMN and BNLI) and the other 2 achieve idAA (PNBN and BBTN).

PEFINDO research the strength of banking industry in Indonesia according to the 10 biggest bank as guide as they strength to facing crisis, and because of they have big impact for health and stability of banking industry overall. PEFINDO valuate the strength of each bank according to Capital Adequacy Ratio (CAR), Non-performing Loan (NPL), profitability or (BOPO) and Liquidity Asset Ratio (LAR). The rating for each item shown on the table below.

Table 1.1. Comparison of the Bank Ratings

\begin{tabular}{|l|c|c|c|c|c|c|c|c|}
\hline \multicolumn{1}{|c|}{ Bank } & Ratings & Prospect & Tot. Asset & CAR & NPL & BOPO & ROAA & LAR \\
\hline BMRI & idAAA & Stabil & 700.1 & $15.0 \%$ & $1.9 \%$ & $62.8 \%$ & $2.6 \%$ & $38.7 \%$ \\
\hline BBRI & idAAA & Stabil & 587.7 & $17.1 \%$ & $1.8 \%$ & $61.3 \%$ & $3.6 \%$ & $28.9 \%$ \\
\hline BBCA & NR & NR & 487.1 & $16.2 \%$ & $0.5 \%$ & $58.6 \%$ & $3.0 \%$ & $29.5 \%$ \\
\hline BBNI & idAAA & Stabil & 362.4 & $0.5 \%$ & $2.4 \%$ & $63.9 \%$ & $2.5 \%$ & $40.2 \%$ \\
\hline BNGA & idAAA & Stabil & 218.2 & $15.6 \%$ & $2.4 \%$ & $71.8 \%$ & $2.1 \%$ & $30.0 \%$ \\
\hline BDMN & idAA+ & Stabil & 173.1 & $15.8 \%$ & $2.3 \%$ & $77.3 \%$ & $2.4 \%$ & $33.7 \%$ \\
\hline BNLI & idAA+ & Stabil & 154.5 & $18.3 \%$ & $1.1 \%$ & $83.2 \%$ & $1.2 \%$ & $24.8 \%$ \\
\hline PNBN & idAA & Stabil & 153.2 & $14.7 \%$ & $1.4 \%$ & $75.6 \%$ & $1.6 \%$ & $21.8 \%$ \\
\hline BNII & idAAA & Stabil & 129.7 & $13.7 \%$ & $1.7 \%$ & $84.8 \%$ & $1.2 \%$ & $32.1 \%$ \\
\hline BBTN & idAA & Stabil & 123.3 & $16.1 \%$ & $4.9 \%$ & $82.2 \%$ & $1.2 \%$ & $26.0 \%$ \\
\hline
\end{tabular}

(Source: PEFINDO)

The local ratings, should not reflect the stock value for each bank, so according to the rating, we would like to be modeled volatility of the stock bank for 2014 and compare which bank have the good volatility model. The ratings that we used are based on Total Asset which consists of BMRI, BBRI, BBCA, BBNI, BNGA, BDMN, BNLI, PNBN, BNII and BBTN.

\section{THEORETICAL BASIS}

Bank is a financial institution that people use to saving or lending money and make some benefit of them. Today, bank not only a place for saving or lending money, but also more than that, people using Bank for a lot function like transfer or exchange media, and so on. According to Somashekar (2009) define that bank connected between saver and lender, which consists of two types that are Central Bank and Commercial Bank. Where Central Bank having function to control commercial bank and economic policy. However, Commercial Bank as financial institution which provide banking for profit.

ARCH model introduced by Engle (1982), it generalize the forecast of variance is not constant. On this model, the mean is zero and the variances conditional on the past is serially uncorrelated with non constant process. ARCH model is the simplest model in econometric, 
but to describe the volatility process of an asset return, it is needed many parameter. Then, Bollerslev (1986) introduced GARCH model as an extension of ARCH model.

Glosten, Jagannathan and Runkle (1993) show that standard GARCH-M is not suitable with conditional mean and conditional volatility result, then by using modified GARCH-M, they find the negative relation on the stock of excess return by looking from conditional mean and conditional variance. Then, Nelson (1991), introduced the new approach of conditional heteroskedasticity to estimate a model of the risk premium. This model is developed a multivariate version exponential ARCH.

Liu, Chiang and Cheng (2012) used the four various GARCH-type model to volatility forecasting of S\&P depositary receipt. The GARCH-type which they used consists of GARCH, IGARCH, EGARCH and CGARCH model. Then, they evaluated the model using statistical loss functions to which consists of Root Mean Squared Error (RMSE), Mean Absolute Percentage Error (MAPE) and Logarithmic Loss Error (LLE). The result is EGARCH model is more accurate for volatility forecast than other GARCH model.

Asai and Brugal (2013) used heterogeneous VAR (HVAR) model to forecasting volatility of Brazil Bovespa Index (Bovespa) stock market and S\&P 500. They develop the HVAR model from GARCH and AR model, the advantage of this approach is we can saving the number of parameter to approximate higher order model. Many researcher using some ARCH/GARCH model to develop their model, but Orhan and Koksal (2012) using 16 kinds of $\mathrm{ARCH} / \mathrm{GARCH}$ model to quantifying risk of VaR under stress time.

They used data from two emerging countries which are Brazil and Turkey, and two developing countries which are Germany and the USA market. The kinds of ARCH/GARCH model which they used consists of ARCH, GARCH, IGARCH, Taylor/Schwert, SAGARCH (Simple Asymmetric GARCH), TGARCH (Threshold GARCH), GJR GARCH, GJR Power GARCH, EGARCH (Exponential GARCH), PGARCH (Power GARCH), NGARCH (Nonlinear GARCH), AGARCH (Asymmetric GARCH), NGARCHK (Nonlinear GARCH with one shift), A-PGARCH (Asymmetric Power GARCH), NPGARCH (Nonlinear Power GARCH) and NPGARCHK (Nonlinear Power GARCH with one shift). The results show that ARCH model is the best model of $\operatorname{GARCH}(1,1)$ and the worst performance shown by NPGARCH and NPGARCHK.

Chung, Liu and Susmel (2012) using the daily ten Asian stock markets to investigate a one-step estimation procedure on the causal relationship between trading volume and stock return, then trading volume and return volatility. On investigating the data, they use a bivariate GJR-GARCH model. The result of their study examine that there is a strong relationship between stock returns and trading, and stock returns and trading volume.

\section{RESEARCH METHOD}

This paper using the daily stock market data of the 10 biggest bank in Indonesia according to total asset of PEFINDO Rating from 1 January 2009 until 31 March 2014. Except for Bank Tabungan Negara, the data begins on 17 December 2009 until 31 March 2014, because it IPO on that time.

The daily stock market data of 10 biggest bank which used in this paper consist of Bank Mandiri (BMRI), Bank Rakyat Indonesia (BBRI), Bank Central Asia (BBCA), Bank 
Negara Indonesia (BBNI), Bank CIMB Niaga (BNGA), Bank Danamon (BDMN), Bank Permata (BNLI), Panin Bank (PNBN), Bank International Indonesia (BNII) and Bank Tabungan Negara (BBTN).

Before we begin developing a model, the row data must in log difference condition. It must do, because the row is not stationary, so to make it stationary we must make it to be $\log$ difference condition. Then, we use log difference because the data which we use is the normal distribution and it guarantee the price of stock is positive. But, if we use just difference, it does not guarantee the price of stock is positive, it can be although in real condition the stock price never be negative.

$$
\text { Return }=\frac{\Delta s}{s}=\frac{s_{t+1}-s_{t}}{s_{t}}=\frac{d s}{s}=d \ln s
$$

On Figure 3.1. It shows the comparison of banks graph with the row data, log differenced data and residual. It shows that, every bank has difference volatility. For BMRI, BBRI, BBCA, BBNI, and BNII have an increasing trend, and other graph very fluctuated, which on a period the stock price very high than goes down. Thus on the residual graph, the residual data (blue line) have same graph with actual data (red line). 
Jurnal Manajemen dan Bisnis: Performa Volume XV Nomor 2 September 2018

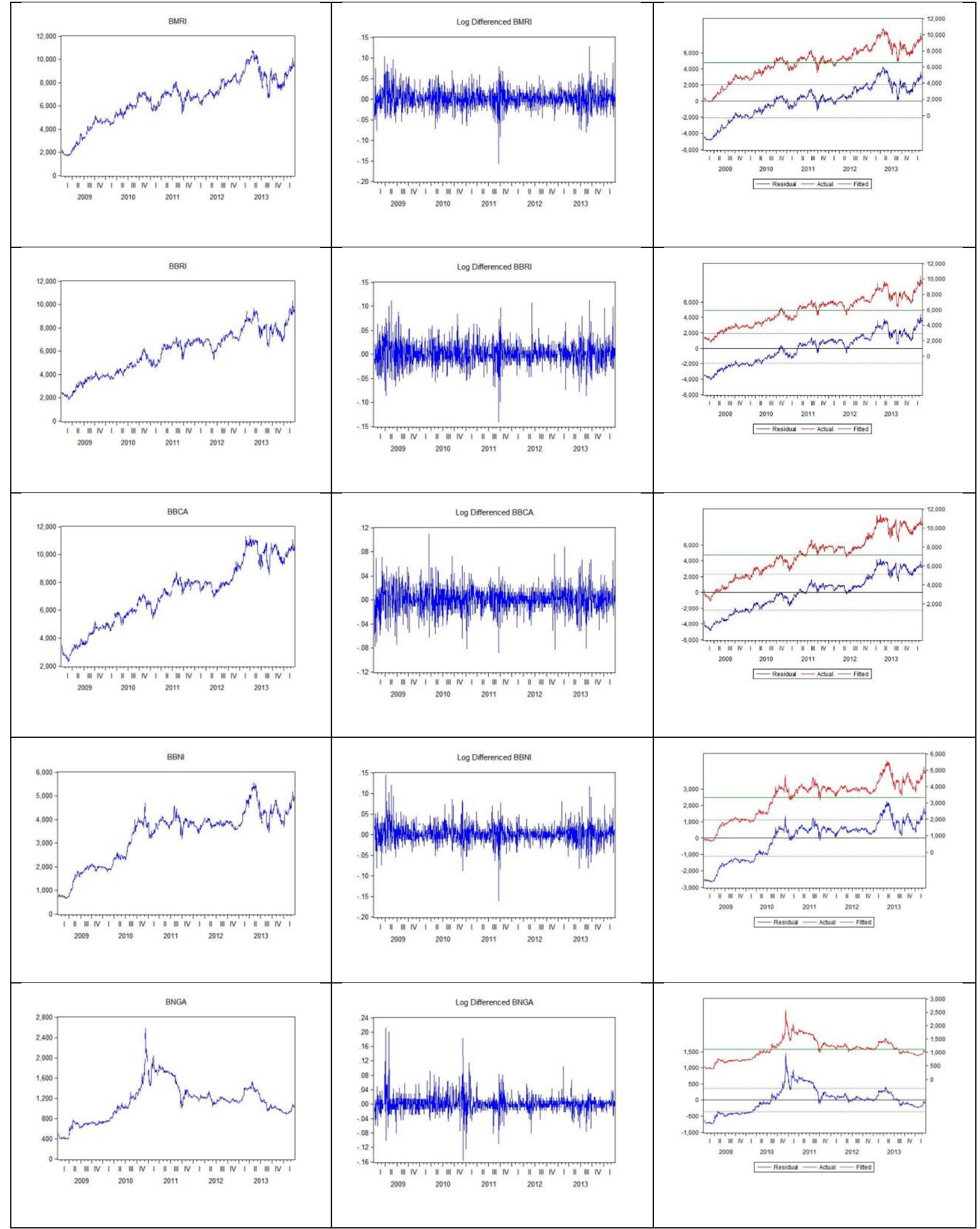


Jurnal Manajemen dan Bisnis: Performa Volume XV Nomor 2 September 2018

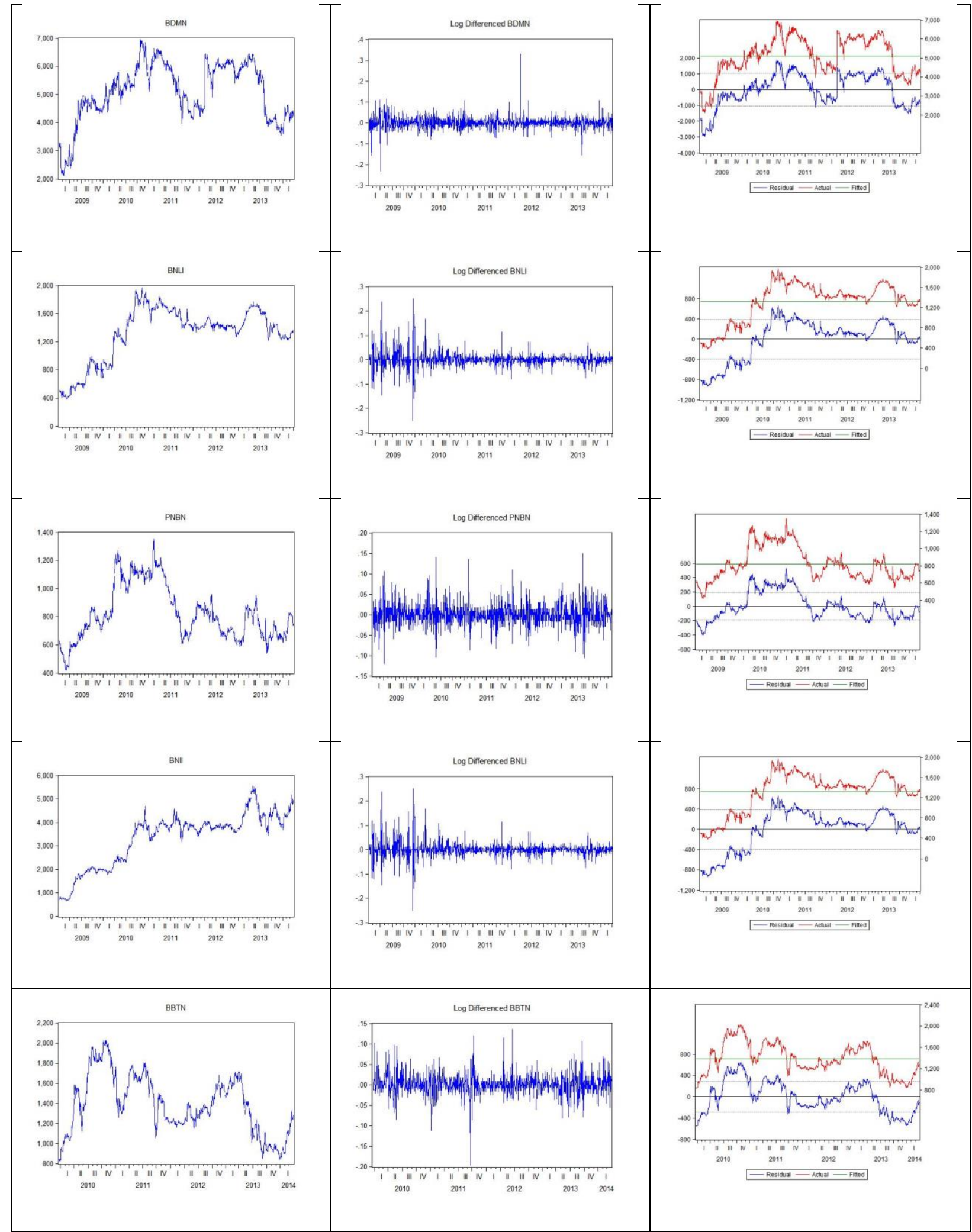

Figure 3.1. The Comparison of The Row Data, Log Differenced ad Residual for the 10 Biggest Bank in Indonesia

Source: Processed Data 


\section{IV.DISCUSSION}

The model that we use on this paper consist of ARCH, GARCH, GJR GARCH or TARCH and EGARCH. For every model, we looking for the best model for each bank by looking for the biggest R-Squared with lowest Akaike Info Criterion (AIC) and Schwartz Criterion (SIC). The result of the evaluating the model shown on table 4.1.

Table 4.1. The Comparison of R-Squared, AIC and SC for each bank

\begin{tabular}{|c|c|c|c|c|c|c|c|c|c|c|c|c|}
\hline \multirow{2}{*}{$\begin{array}{c}\text { CODE } \\
\text { OF } \\
\text { BANK }\end{array}$} & \multicolumn{3}{|c|}{ ARCH } & \multicolumn{3}{|c|}{ GARCH } & \multicolumn{3}{|c|}{ TARCH } & \multicolumn{3}{|c|}{ EGARCH } \\
\hline & $\begin{array}{c}\mathrm{R}- \\
\text { squared }\end{array}$ & AIC & $\mathrm{SC}$ & $\begin{array}{c}\mathrm{R}- \\
\text { squared }\end{array}$ & AIC & $\mathrm{SC}$ & $\begin{array}{c}\mathrm{R}- \\
\text { squared }\end{array}$ & AIC & SC & $\begin{array}{c}\mathrm{R}- \\
\text { squared }\end{array}$ & AIC & $\mathrm{SC}$ \\
\hline BMRI & 0.986832 & 16.60388 & 16.62009 & 0.993537 & 15.73226 & 15.75252 & 0.993982 & 15.21062 & 15.23493 & 0.99407 & 12.74646 & 12.77077 \\
\hline BBRI & 0.990676 & 16.47992 & 16.49613 & 0.994178 & 12.79658 & 12.81685 & 0.988495 & 15.84221 & 15.86652 & 0.994173 & 12.60263 & 12.62695 \\
\hline BBCA & 0.99434 & 16.8482 & 16.86441 & 0.994911 & 16.09094 & 16.1112 & 0.992709 & 16.13948 & 16.16379 & 0.995672 & 12.70648 & 12.7308 \\
\hline BBNI & 0.994134 & 15.4659 & 15.48211 & 0.994916 & 14.63328 & 14.65354 & 0.994929 & 14.49499 & 14.51931 & 0.994945 & 11.26028 & 11.28459 \\
\hline BNGA & 0.991808 & 9.334798 & 9.351008 & 0.991942 & 9.77508 & 9.795343 & 0.991718 & 12.00042 & 12.02474 & 0.991938 & 9.082361 & 9.106677 \\
\hline BDMN & 0.983032 & 15.31256 & 15.32877 & 0.982959 & 14.43854 & 14.4588 & 0.983076 & 15.0726 & 15.09692 & 0.983071 & 12.60089 & 12.62521 \\
\hline BNLI & 0.967507 & 13.28905 & 13.30526 & 0.992663 & 12.59984 & 12.6201 & 0.993159 & 12.65447 & 12.67878 & 0.993997 & 9.37753 & 9.401846 \\
\hline PNBN & 0.987355 & 8.943772 & 8.959982 & 0.987357 & 8.990424 & 9.010687 & 0.972249 & 11.45608 & 11.4804 & 0.987325 & 8.874257 & 8.898573 \\
\hline BNII & 0.970605 & 15.38331 & 15.39952 & 0.990683 & 14.64656 & 14.66682 & 0.99489 & 14.65544 & 14.67975 & 0.994948 & 11.25757 & 11.28189 \\
\hline BBTN & 0.985773 & 9.85147 & 9.870555 & 0.984353 & 11.97428 & 11.99814 & 0.985768 & 9.807372 & 9.836 & 0.985778 & 9.805989 & 9.834617 \\
\hline
\end{tabular}

Source: Processed Data

From the table 4.1. The best model fitted for each bank is EGARCH. It shown from the highest R-squared and the lowest AIC and SIC value. Then, by using this information, we can do double checking to ensure the model is good fitted or not. On this paper, we use two methods to checking the model:

\subsection{Time Series Diagnostic Checking}

By using the information on Table 4.1 we can execute the diagnostic checking for the EGARCH model. This model consists of Serial Correlation checking, ARCH effect checking and Normal Distributed checking.

\subsubsection{Serial Correlation}

On this Serial Correlation checking, we see the Q-STAT and Probability of the model with hypothesis:

$\mathrm{H}_{0} \quad$ : There is no Serial Correlation

$\mathrm{H}_{1} \quad$ : There is Serial Correlation 


\subsubsection{ARCH Effect Test}

On the ARCH Effect Test, we see the Prob. Chi-Square with hypothesis:

$\mathrm{H}_{0} \quad$ : There is no ARCH Effect

$\mathrm{H}_{1}$ : There is ARCH Effect

\subsubsection{Normal Distributed} hypothesis:

By using Histogram-Normality Test, we can the model normal distributed or no with

$\mathrm{H}_{0} \quad$ : Residual are normally distributed

$\mathrm{H}_{1} \quad$ : Residual are no normally distributed

The good fitted volatility model will be accepted if it is no Serial Correlation, no ARCH Effect and residual are Normal Distributed. With this assumption, we can conclude that:

- If Q-stat and probability of Serial Correlation > 0.05 it means that there is an evidence to accept the $\mathrm{H}_{0}$;

- If the probability of ARCH Test $>0.05$ it means that there is an evidence to accept the $\mathrm{H}_{0}$; and

- If the probability on Normality test $(\mathrm{p}$-value $=0$ ), it means that the residual is normal distributed 
Jurnal Manajemen dan Bisnis: Performa Volume XV Nomor 2 September 2018

Table 4.2. Time Series Diagnostic Checking

\begin{tabular}{|c|c|c|c|}
\hline $\begin{array}{c}\text { Code of } \\
\text { Bank }\end{array}$ & Serial Correlation & ARCH Test & $\begin{array}{c}\text { Normal } \\
\text { Distribution }\end{array}$ \\
\hline BMRI & Q-statistics \& Probability $>0.05$ & 0.7738 & 0 \\
\hline BBRI & Q-statistics \& Probability $>0.05$ & 0.0669 & 0 \\
\hline $\mathrm{BBCA}$ & There are some lag $<0.05$ & 0 & 0 \\
\hline BBNI & Q-statistics \& Probability > 0.05 & 0.1171 & 0 \\
\hline BNGA & Q-statistics \& Probability > 0.05 & 0.434 & 0 \\
\hline BDMN & There are some lag $<0.05$ & 0.9104 & 0 \\
\hline BNLI & There are some lag $<0.05$ & 0.6517 & 0 \\
\hline PNBN & Q-statistics \& Probability > 0.05 & 0.0824 & 0 \\
\hline BNII & Q-statistics \& Probability > 0.05 & 0.1091 & 0 \\
\hline BBTN & Q-statistics \& Probability $>0.05$ & 0.1931 & 0 \\
\hline
\end{tabular}

Source: Processed Data

According to the Table 4.2. We use time series diagnostic checking to examine EGACRH model for every bank. The result is almost all bank have good fitted volatility on EGARCH model, but for BBCA, BDMN, and BNLI, the EGARCH model having serial correlation. On BBCA, not only it has serial correlation, it has ARCH test too although the probability is zero.

\subsection{Fitted Model Performance Measurement}

Liu and Shi (2013) used this method is to ensure the prediction accuracy of each model. Although there is some statistical measure method which consists of Root Mean Squared Error (RMSE), Mean Absolute Error (MAE), Mean Absolute Percentage Error (MAPE), and Theil's Inequality Coefficient (TIC).

$$
\begin{gathered}
M A E=\frac{1}{n} \sum_{i=1}^{n}\left|y_{p i}-y_{a i}\right| \\
M A P E=\frac{1}{n} \sum_{i=1}^{n}\left|\frac{y_{p i}-y_{a i}}{y_{a i}}\right| \\
R M S E=\sqrt{\frac{1}{n} \sum_{i=1}^{n}\left(y_{p i}-y_{a i}\right)^{2}} \\
T I C=\frac{\sqrt{\frac{1}{n} \sum_{i=1}^{n}\left(y_{p i}-y_{a i}\right)^{2}}}{\sqrt{\frac{1}{n} \sum_{i=1}^{n} y_{p i}{ }^{2}}+\sqrt{\frac{1}{n} \sum_{i=1}^{n} y_{a i}{ }^{2}}}
\end{gathered}
$$


Where $n$ is the observation number of the testing dataset, $y_{a i}$ is the actual data and $y_{p i}$ is the predicted values. The fitted volatility model performance measurement result of the model is on the Table 5. The error number of each bank of each model having difference value and difference model which good fitted volatility (on the red number). We can see that there are 4 bank (BMRI, BBCA, BNLI, and BNII) which fitted volatility with EGARCH model, 1 bank (BBTN) fitted volatility with TARCH model, 2 bank (BBRI and BNGA) fitted volatility with GARCH model, and 1 bank (PNBN) fitted volatility with ARCH model. And other 2 banks have spread results, which BBNI having good MAE and MAPE on TARCH model, and good RMSE and TIC on EGARCH model, then BDMN having good MAE and MAPE on ARCH model, and good RMSE and TIC on EGARCH model. 
Jurnal Manajemen dan Bisnis: Performa Volume XV Nomor 2 September 2018

Table 4.3. Fitted Model Performance Measurement

\begin{tabular}{|c|c|c|c|c|c|c|c|c|c|c|c|c|c|c|c|c|}
\hline \multirow{2}{*}{$\begin{array}{c}\text { Code } \\
\text { of } \\
\text { Bank }\end{array}$} & \multicolumn{4}{|c|}{ ARCH } & \multicolumn{4}{|c|}{ GARCH } & \multicolumn{4}{|c|}{ TARCH } & \multicolumn{4}{|c|}{ EGARCH } \\
\hline & MAE & MAPE & RMSE & TIC & MAE & MAPE & RMSE & TIC & MAE & MAPE & RMSE & TIC & MAE & MAPE & RMSE & TIC \\
\hline BMRI & 185.94394 & 0.03812 & 233.63164 & 0.03395 & 121.17595 & 0.02045 & 163.68265 & 0.02390 & 113.82272 & 0.01823 & 157.94899 & 0.02309 & 113.04880 & 0.01803 & 156.78117 & 0.02291 \\
\hline BBRI & 140.04355 & 0.02826 & 183.73228 & 0.02955 & 101.45261 & 0.01812 & 145.18905 & 0.02344 & 159.16846 & 0.03273 & 204.09317 & 0.03275 & 101.65740 & 0.01814 & 145.25451 & 0.02344 \\
\hline BBCA & 128.45502 & 0.02027 & 170.91447 & 0.02269 & 119.66714 & 0.01835 & 162.05881 & 0.02152 & 149.83221 & 0.02468 & 193.99003 & 0.02571 & 106.38025 & 0.01552 & 149.46115 & 0.01991 \\
\hline BBNI & 61.44645 & 0.02276 & 86.41345 & 0.02455 & 53.11402 & 0.01652 & 80.44689 & 0.02287 & 52.87686 & 0.01637 & 80.34294 & 0.02284 & 53.08639 & 0.01645 & 80.22039 & 0.02281 \\
\hline BNGA & 18.20660 & 0.01621 & 32.66730 & 0.02778 & 17.55620 & 0.01542 & 32.39851 & 0.02747 & 18.25528 & 0.01616 & 32.84546 & 0.02781 & 17.67931 & 0.01556 & 32.40808 & 0.02750 \\
\hline BDMN & 89.35270 & 0.01840 & 133.90195 & 0.02577 & 91.63500 & 0.01904 & 134.18846 & 0.02581 & 89.74511 & 0.01848 & 133.72890 & 0.02574 & 89.80273 & 0.01848 & 133.74863 & 0.02575 \\
\hline BNLI & 61.00516 & 0.05510 & 69.60561 & 0.05251 & 22.51011 & 0.02139 & 33.07481 & 0.02407 & 21.24681 & 0.01977 & 31.93833 & 0.02326 & 18.76289 & 0.01654 & 29.91723 & 0.02183 \\
\hline PNBN & 14.64109 & 0.01810 & 21.72376 & 0.02577 & 14.66383 & 0.01815 & 21.72209 & 0.02576 & 24.63714 & 0.03049 & 32.18304 & 0.03787 & 14.80077 & 0.01829 & 21.74940 & 0.02582 \\
\hline BNII & 151.36186 & 0.08031 & 193.44758 & 0.05602 & 86.00775 & 0.03843 & 108.91236 & 0.03125 & 54.89729 & 0.01796 & 80.65965 & 0.02295 & 53.25867 & 0.01652 & 80.19548 & 0.02277 \\
\hline BBTN & 24.03372 & 0.01779 & 34.45587 & 0.02431 & 25.85318 & 0.01931 & 36.13446 & 0.02562 & 23.95536 & 0.01770 & 34.46145 & 0.02432 & 23.97015 & 0.01772 & 34.44893 & 0.02432 \\
\hline
\end{tabular}

Source: Processed Data

ISSN: 1829-8680 E-ISSN: 2599-0039 


\section{CONCLUSION}

This paper examines the fitted volatility model of the 10 biggest bank in Indonesia according to PEFINDO rating by using ARCH, GARCH, TARCH and EGARCH. All of the bank model having high R-squared, then low AIC and SIC, and the highest R-squared is on EGARCH model. But when we check the model using time series diagnostic checking and fitted model performance measurement, the result is not all of the banks is fitted volatility with EGARCH model.

On time series diagnostic checking, there are 3 banks which have serial condition and 1 bank which have ARCH test. Then, according to fitted model performance measurement, only 4 banks which fitted volatility with EGARCH model, and other banks have spread result.

\section{REFERENCES}

Asai, M. \& Brugal, I. (2013). Forecasting Volatility via Stock Return, Range, Trading Volume and Spillover Effect. North American Journal of Economics and Finance, 25, 202-213.

Bollerslev, T. (1986). Generalized Autoregressive Conditional Heteroskedasticity. Journal of Econometrics, 31, 307-327.

Chuang, W. I., Liu, H. H., Susmel, R. (2012). The Bivariate GARCH Approach to Investigating The Relation Between Stock Returns, Trading Volume, and Return Volatility. Global Finance Journal, 23, 1-15.

Engle, R. F. (1982). Autoregressive Conditional Heteroscedasticity with Estimates of The Variance Of United Kingdom Inflation. Econometrica, 50, 987-1007.

Glosten, L. R., Jagannathan, R., Runkle, D. (1993). On the relation between the expected value and the volatility of the nominal excess return on stocks. Journal of Finance, 48, $1779-1801$.

Hanniffy, G. (2014). Posisi 10 Bank Terbesar Tetap Kuat di 2014. PEFINDO Article.

Liu, H., Jing, S. (2013). Applying ARMA-GARCH Approaches To Forecasting Short-Term Electricity Prices. Energy Economics, 37, 152-166.

Liu, H. C., Chiang, S. M., \& Cheng, N. Y. P. (2012). Forecasting The Volatility of S\&P Depositary Receipts Using GARCH-type Models Under Intraday Range-based and Return-based Proxy Measures. International Review of Economics and Finance, 22, 7891.

Nelson, D. B. (1991). Conditional heteroskedasticity in asset returns: A new approach. Econometrica, 59, 347-370.

Orhan, M., Koksal, B. (2012). A Comparison of GARCH Models for VaR Estimation. Expert Systems with Applications, 39, 3582-3592. 
Jurnal Manajemen dan Bisnis: Performa Volume XV Nomor 2 September 2018

Somashekar, N.T. (2009). Banking. Daryaganj, New Delhi: New Age International Publishers.

Tsay, R. S. (2010). Analysis of Financial Time Series Third Edition. Hoboken, New Jersey: John Wiley \& Sons, Inc. 